Article

\title{
Greenhouse Gas Abatement Potentials and Economics of Selected Biochemicals in Germany
}

\author{
Frazer Musonda ${ }^{1,2, *(\mathbb{D})}$, Markus Millinger ${ }^{1}(\mathbb{D})$ and Daniela Thrän ${ }^{1,2,3}$ (D) \\ 1 Department of Bioenergy, Helmholtz Centre for Environmental Research-UFZ Permoserstraße 15, \\ 04318 Leipzig, Germany; markus.millinger@ufz.de (M.M.); daniela.thraen@ufz.de (T.D.) \\ 2 Institute for Infrastructure and Resources Management, University Leipzig, Grimmaische Str. 12, \\ 04109 Leipzig, Germany \\ 3 DBFZ Deutsches Biomasseforschungszentrum gemeinnützige $\mathrm{GmbH}$, Torgauer Straße 116, \\ 04347 Leipzig, Germany \\ * Correspondence: frazer.musonda@ufz.de
}

Received: 13 February 2020; Accepted: 8 March 2020; Published: 12 March 2020

check for updates

\begin{abstract}
In this paper, biochemicals with the potential to substitute fossil reference chemicals in Germany were identified using technological readiness and substitution potential criteria. Their greenhouse gas (GHG) emissions were quantified by using life cycle assessments (LCA) and their economic viabilities were determined by comparing their minimum selling prices with fossil references' market prices. A bottom up mathematical optimization model, BioENergy OPTimization (BENOPT) was used to investigate the GHG abatement potential and the corresponding abatement costs for the biochemicals up to 2050. BENOPT determines the optimal biomass allocation pathways based on maximizing GHG abatement under resource, capacity, and demand constraints. The identified biochemicals were bioethylene, succinic acid, polylactic acid (PLA), and polyhydroxyalkanoates (PHA). Results show that only succinic acid is economically competitive. Bioethylene which is the least performing in terms of economics breaks even at a carbon price of 420 euros per ton carbon dioxide equivalent $\left(€ / \mathrm{tCO}_{2} \mathrm{eq}\right)$. With full tax waivers, a carbon price of $134 € / \mathrm{tCO}_{2} \mathrm{eq}$ is necessary. This would result in positive margins for PHA and PLA of $12 \%$ and $16 \%$, respectively. From the available agricultural land, modeling results show high sensitivity to assumptions of carbon dioxide $\left(\mathrm{CO}_{2}\right)$ sequestration in biochemicals and integrated biochemicals production. GHG abatement for scenarios where these assumptions were disregarded and where they were collectively taken into account increased by $370 \%$ resulting in a $75 \%$ reduction in the corresponding GHG abatement costs.
\end{abstract}

Keywords: biochemicals; biobased polymers; bioeconomy; greenhouse gas (GHG) abatement; GHG abatement scenario analysis; optimal biomass allocation

\section{Introduction}

The use of renewable resources in replacing fossil counterparts has been promoted as part of efforts to mitigate the impact of anthropogenic greenhouse gas (GHG) emissions on the environment. In the context of the European Union, this has led to the formulation of directives such as the renewable energy directives (REDs) which sets out targets for member states [1]. By 2020, member states are to achieve a mandatory target of $20 \%$ share of energy from renewable resources and $10 \%$ minimum target for biofuels. This directive was in December 2018 revised to establish a new binding renewable energy target of at least $32 \%$ by 2030 for the European Union [2]. To achieve this, support mechanisms such as subsidies, biofuel quotas, tax exemptions, and priority access or guaranteed access to the grid system for electricity from renewable resources have been proposed [3,4]. 
As a result of such support mechanisms, biomass has found increased application in the power, heat, and fuel sectors in recent years [5,6]. The biochemicals sector has, however, not received similar support and this coupled with a lower cost advantage of fossil counterparts [7] has resulted in the sector being underdeveloped relative to the biofuel and bioenergy sectors. The petrochemicals sector is energy intensive with high corresponding GHG emissions thus equally important in tackling anthropogenic $\mathrm{CO}_{2}$ emissions. In Germany for the year 2014, the energy related GHG emissions were 47 million tons which accounted for $18 \%$ of total emissions in the industry sector [8]. In the same year, the energy consumption for the European Union (EU) chemical industry including pharmaceuticals amounted to 612 terawatt-hour (TWh), representing $19.5 \%$ of the overall industrial energy consumption in the EU [9]. According to the IEA and de la Rue du Can and Price, as cited in [10], of the global GHG emissions from the industry (which represents 30\% of total global GHG emissions), the chemicals industry contributed $15 \%$ of total global emissions in 2010.

The emergence of systems perspective thinking in environmental management and biorefineries in the context of a bioeconomy has propelled discussions of the role of biochemicals in substituting petrochemical counterparts. Unlike the power, heat, and fuel sectors which have unique final products, a myriad of chemicals can be produced from biomass and fossil feedstocks.

Previously, efforts have been made to analyze high potential platform biochemicals [7,11-13]. Werpy and Petersen [13] identified twelve building block biochemicals from sugars using chemical and biological transformation processes. They narrowed their selection of high potential biochemicals from 300 to 12 by using an iterative review process in which the chemical and market production data, estimates of material and performance properties were used as the basis for selection. The European Commission Directorate-General Energy [11] identified 25 biochemicals of particular interest based on the level of industrial activity. They analyzed the technological readiness level (TRL) of the biochemical technologies and their production volumes for the selection process.

However, in order to establish the relevance of biochemicals in terms of climate protection, it is imperative to further the selection criteria by establishing the petrochemical reference substitution potentials based on petrochemical reference production volumes. This, according to the authors' knowledge has not been done in literature.

In literature, efforts have been made to assess the environmental and economic performance of biochemicals. Hermann et al. [14] analyzed the potential GHG savings of selected biochemicals by comparison with identical or functionally equivalent petrochemicals. Using the same approach of life cycle emissions and fossil reference, [15] found that bioproducts had the potential to save 39\% to $86 \%$ of GHG emissions in the baseline scenarios they considered. An analysis of the economic viability of biochemicals by Hermann and Patel [16], determined that bioethanol, 1,3 propane diol, polytrimethylene terephthalate, and succinic acid were economically viable at crude oil prices of $\$ 25 /$ barrel and prices for fermentable sugar at between 70 and $400 € / t$. Bioethylene and polylactic acid (PLA) were found to be economically viable for a higher crude oil price of US $\$ 50 /$ barrel. However, with assumptions suiting the German perspective, GHG life cycle assessments and economic analysis for biochemicals have not been done in literature. Different electricity grid mixes, assumptions for heating and agricultural practices have big impacts on GHG life cycle accessment (LCA) results. Different considerations for combined taxes (i.e., corporate income tax, trade tax, solidarity surcharge) and feedstock costs equally affect the final results for economic analyses. It is therefore important to assess the economic and environmental performances of the identified biochemicals within the scope of Germany to analyze the potential contribution they possess.

The consideration of biochemicals in biomass allocation models to envisage their potential contributions to climate mitigation has been missing in literature. One challenge that hinders the inclusion of biochemicals in modeling exercises is the complex nature of the product portfolio for the biochemicals. Numerous chemicals can be produced from the available biomass, which presents a challenge for choice of a system boundary for modeling. For example, ethylene can be used as a precursor for the manufacture of polyethylene, rubbers, polyester, polyvinyl chloride (PVC), etc. that 
are smaller in fraction. Studies that have been carried out on modeling biomass allocation to different competing uses have primarily focused on optimizing bioenergy systems [17-20]. To the knowledge of the authors, no work has previously been done where:

- High potential biochemicals were identified based on a combination of TRL and production volumes of petroleum counterparts;

- Economic analyses and GHG life cycle assessments were performed with German system considerations in order to better understand the level of GHG abatement potentials and the economic implications; and

- Mathematically optimized the allocation of limited biomass resources to the biochemical technologies to determine the potential optimal GHG abatement and the corresponding abatement costs.

In this regard, this work was based on addressing these research gaps identified from literature. The study will contribute to the debate regarding effective biomass utilization strategies for GHG abatement with a special focus on relevant biochemicals by highlighting their GHG abatement potentials and economics.

\section{Materials and Methods}

The methodological steps followed in the study are summarized in Figure 1. Biochemicals with the technical potential to substitute fossil counterparts and whose potential substitution (production volumes) are significant were selected as the first step. In the second step, environmental and economic assessments on this subgroup of biochemicals were conducted to determine their environmental and economic performances. The environmental and economic assessments were all done in reference to fossil reference technologies. Based on how they could compete for biomass feedstocks in Germany with GHG abatement maximization as the objective function, the selected biochemicals were mathematically modeled in the last step.

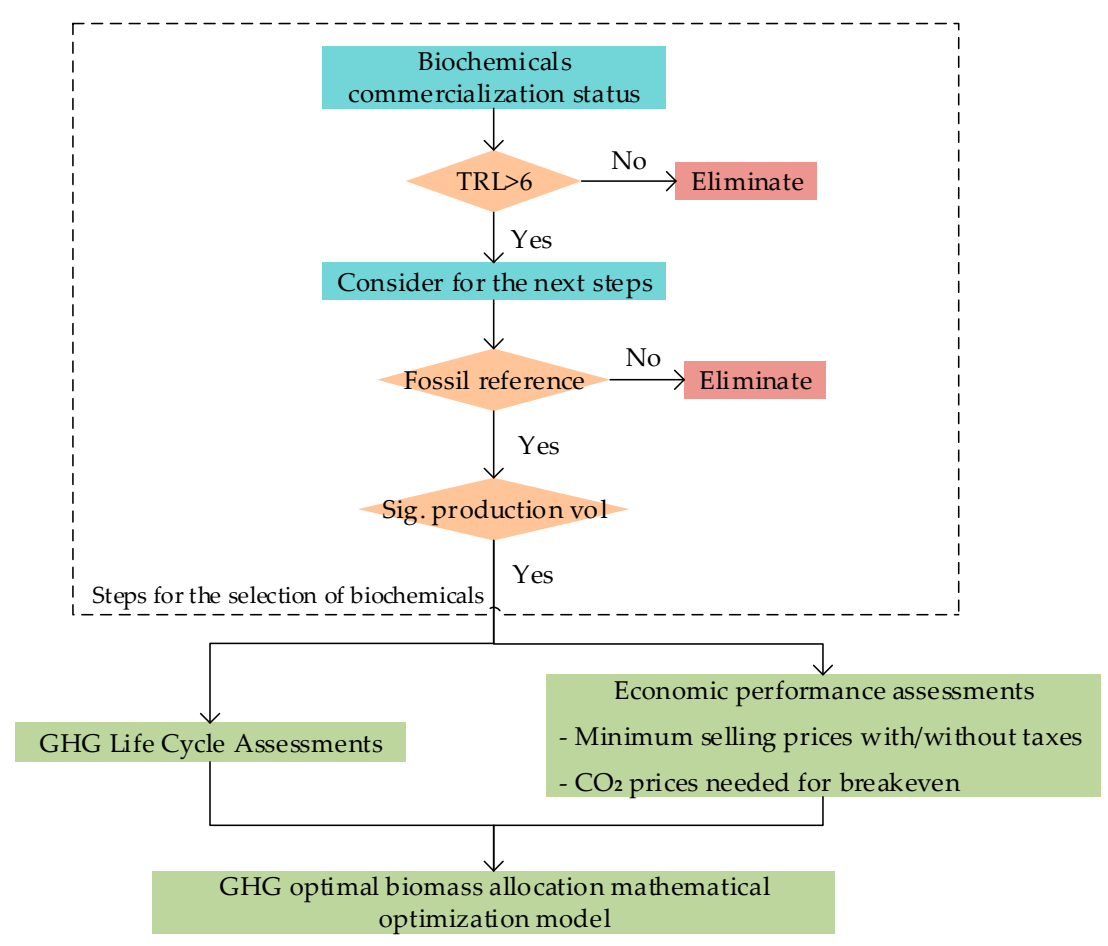

Figure 1. Methodological process steps for the selection and assessment of biochemicals in Germany. In the figure, TRL stands for technological readiness level, GHG stands for greenhouse gas, $\mathrm{CO}_{2}$ stands for carbon dioxide while "Sig. production vol" stands for "significant production volumes". 


\subsection{Biochemicals Selection}

In this work, the study results of the European Commission Directorate [11] were used as a basis for the biochemicals selection. The selection criterion was broadened by considering biochemicals with a technological readiness level (TRL) between 6 and 9, meaning that these technologies are either in their demonstration phase, in which case they have a high probability of commercial relevance in the near future, or they are already commercially available. The selection criterion was thereafter expanded for this subgroup of biochemicals by contextualizing their substitution potentials to the case of Germany. This was done by considering production volumes of their fossil counterparts shown in Table 1. The petrochemicals production volumes in Table 1 are based on a seven-year (i.e., between 2010 and 2017) average production. Petrochemicals prices data are difficult to find in the public domain. In Table 1, only prices for ethylene, propylene, benzene, and xylenes are shown because price data for other chemicals was not found.

Table 1. Average production volumes and prices for the fossil references between 2010 and 2017 [21].

\begin{tabular}{ccc}
\hline Chemical & Million Tons & $\boldsymbol{\ell}$ /ton \\
\hline Ethylene & 5.06 & 1076 \\
Propylene & 3.95 & 965 \\
Butene and its isomers Buta-1,3-diene & 2.30 & \\
Methanol & 1.00 & \\
Benzene & 1.90 & 819 \\
Toluene & 0.64 & \\
Xylene o,p & 0.55 & 877; 941 \\
Acetic acid & 0.05 & \\
Ethylene dichloride & 2.41 & \\
Ethylene oxide & 1.00 & \\
Ethylene glycol & 0.26 & \\
Propylene oxide & 0.82 & \\
Propylene glycol & 0.40 & \\
Ammonia & 2.60 & \\
Polyvinyl chloride & 1.71 & \\
Polystyrenes & 0.62 & \\
Polypropylene & 1.94 & \\
Polyurethanes & 1.22 & \\
Polyamides & 1.06 & \\
\hline o,p represent the isomers of Xylene 1,2-Dimethylbenzene, and 1,4-Dimethylbenze.
\end{tabular}

\subsubsection{Petrochemical Value Chain}

In order to have an understanding of the fossil reference technologies and the substitution potential, an analysis for the petrochemical value chain (shown in Figure 2) and the average inventories (production volumes) for the years 2010-2017 in Germany was done. Fossil derived chemicals, i.e., petrochemicals are chemicals derived from crude oil, natural gas, and sometimes coal. The chemicals sector is very heterogeneous in terms of product portfolios. These diverse products are derived from seven main primary petrochemicals: Ethylene, propylene, butadiene, benzene, toluene xylenes, and methanol. Figure 3 highlights the major petrochemical value chains.

\subsubsection{Selected Biochemicals}

Bioethylene, a drop in the biochemical with the same structure and properties as fossil-based ethylene was chosen as a replacement for fossil-based ethylene. According to [11], bioplastics PLA and polyhydroxyalkanoates (PHA) can substitute polystyrene (PS). PLA and PLA were therefore chosen to replace PS for this work. Succinic acid can be used as a precursor for the manufacture of 1,4-Butanediol, polyamides, polybutyrate succinate, and polyurethanes. Based on the average production volume for polyurethanes, succinic acid which can replace fossil-based adipic acid in 
polyurethanes production was chosen. The remaining biochemicals from the list either have fossil reference chemicals with minimal production volumes or have no reference fossil chemicals such as sorbitol which has applications in the food industry. Another is Furfural, which despite being used as a solvent, lubricant, gasoline additive, and as a precursor for polymers and resins [23], a specific fossil reference is difficult to establish because of the many fossil equivalents that have similar applications. However, with its versatility and being derived from lignocellulosic biomass it would become relevant.

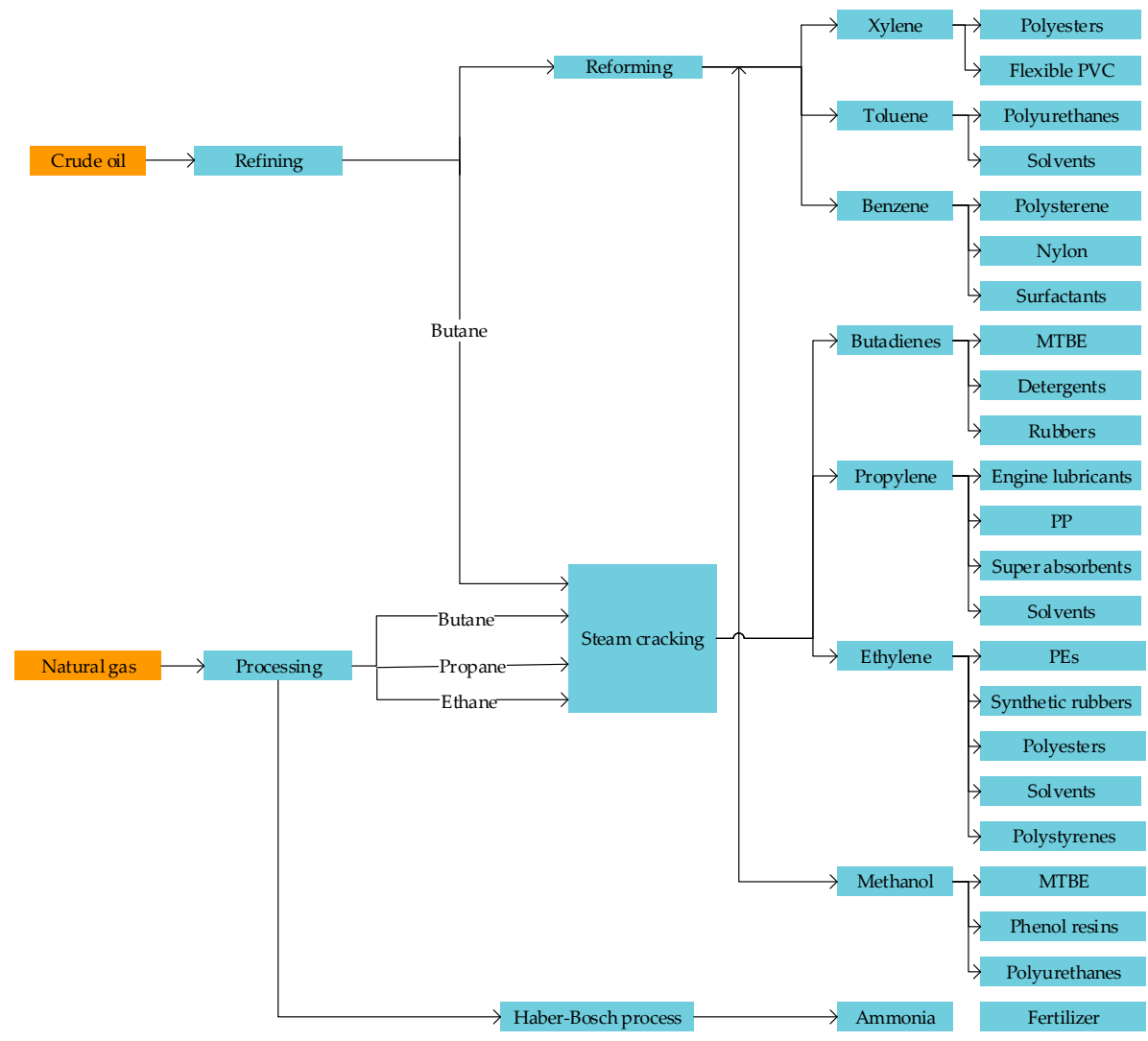

Figure 2. Petrochemical value chains for selected products adapted from [13,22]. In the figure, PVC is polyvinyl chloride, PP is polypropylene, PE is polyethylene, and MTBE is methyl tert-butyl ether.

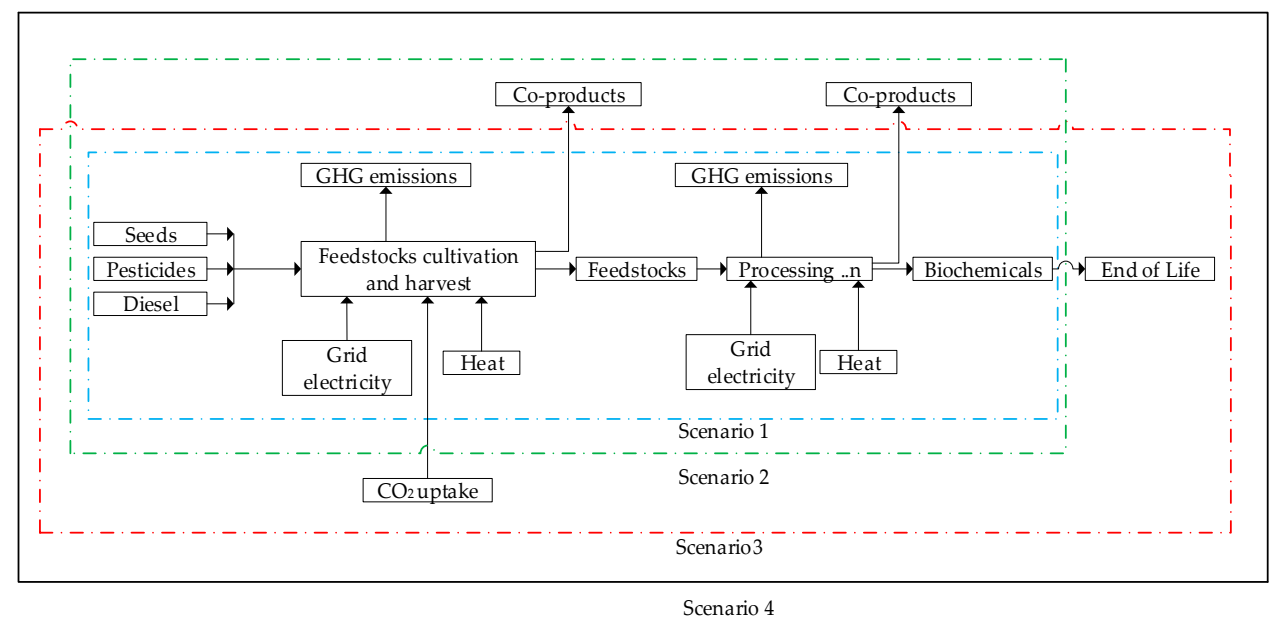

Figure 3. System boundaries (shown by the dotted and black bold lines) for the life cycle greenhouse gas (GHG) emissions considered in the scenarios. ' $n$ ' represents different processing steps. 


\subsection{GHG Life Cycle Emissions Assessments}

A literature review was undertaken in order to establish life cycle inventory data for the biochemicals and GHG footprints for their fossil counterparts. This was then adapted to current existing conditions for the electric grid mix in Germany. The functional unit considered was 1 ton of biochemical. All the GHG emissions for every biochemical from cultivation of feedstocks and the processing of biomass to make biochemicals were added. This value was then subtracted from a reference fossil chemical in order to determine the amount of GHG savings that can be realized when a ton of petrochemical is substituted by a biochemical counterpart. Different system boundaries were considered and this is highlighted in detail in Section 2.5. Data considered for the cultivation of feedstocks and processing of the feedstocks to desired biochemicals is summarized in Table 2. For the production of biochemicals sugar beets were used as feedstocks for bioethylene while corn grains for succinic acid, PHA, and PLA.

Table 2. Key values for cultivation and processing of feedstocks adapted from [24-30].

\begin{tabular}{cccccc}
\hline & & Bioethylene & Succinic Acid & Polyhydroxyalkanoates (PHA) & Polylactic acid (PLA) \\
\hline Cultivation & Units & Sugar beets & Corn & Corn & Corn \\
Yield_2015 & tFM/ha & 65 & 9.3 & 9.3 & 9.3 \\
Yield_2050 & tFM/ha & 65 & 9.3 & 9.3 & 9.3 \\
Seed & $\mathrm{kg} / \mathrm{ha}$ & 6 & 30 & 30 & 30 \\
K2O fertilizer & $\mathrm{kg} / \mathrm{ha}$ & 135 & 67 & 67 & 57 \\
P2O5 & $\mathrm{kg} / \mathrm{ha}$ & 59.7 & 55 & 55 & 55 \\
fertilizer & $\mathrm{kg} / \mathrm{ha}$ & 400 & 283 & 283 & 283 \\
Lime & 120 & 107 & 107 & 107 \\
Nitrogenous & $\mathrm{kg} / \mathrm{ha}$ & 0.6 & 0.6 & 0.6 \\
fertilizer & $\mathrm{kg} / \mathrm{ha}$ & 1.3 & 55 & 55 & 55 \\
Pesticides & $\mathrm{L} / \mathrm{ha}$ & 175.9 & Corn & Corn & Corn \\
Diesel & Units & Sugar beets & 819 & 1804 & 5266 \\
\hline Processing & $\mathrm{MJ} / \mathrm{tFM}$ & 1381.2 & 1480 & 1015 & 1286 \\
Process heat & $\mathrm{kWh} / \mathrm{tFM}$ & 65.72 & & & \\
Electricity & $\mathrm{m}$ & & &
\end{tabular}

\subsection{Economic Assessments}

Capital costs, feedstock costs, and operation costs associated with the production of the biochemicals were gathered from publicly available data sources. An assumption of 20 years plant life was made for all the technological options. Based on these data, the economic viabilities of biochemical investments were assessed by determining the minimum selling price and compared with the market prices for fossil reference technologies. The minimum selling price is the lowest price at which a biochemical product can be sold in order not to incur a loss. Therefore, this was determined at a point where the total costs (TC) are equal to the minimum selling prices $P_{\min }$ according to Equation (1). Total costs include the marginal costs and investment costs. Marginal costs are the feedstock costs, operation and maintenance costs, and taxes minus co-product income. Taxes refer to the combined taxes (corporate income tax, trade tax, solidarity surcharge) which is taken as $30 \%$ for Germany according to [31]. The discounted annualized investment costs $I^{(t)}$ are calculated at a rate of $7 \%$ (Equation (2)). The internal rate of return is $i$, the plant life time is $\hat{t}$, and the total investment cost is $I^{(0)}$. The capacity factor was assumed at $92 \%$ of the total capacity for all the biochemical production plants.

$$
\begin{gathered}
P_{\min }=T C \\
I^{(t)}=\frac{i *(i+1)^{\hat{t}}}{(i+1)^{\hat{t}}-1} * I^{(0)}
\end{gathered}
$$

The minimum selling prices for the biochemicals were analyzed in comparison with their fossil references with and without taxes. 
The capital costs and fixed operation and maintenance costs are summarized in Table 3. The capital costs were converted to 2015 US dollars and then to Euros using the 2015 average EUR/USD exchange rate of 1.11 according to [32]. The price for sugar beets in Germany could not be found, therefore an average price across Europe was taken from [33]. The price for corn grains was taken from [34]. The market price for ethylene was taken from [35]. The 2015 market prices for adipic acid and polystyrene were not found, therefore an average for August 2013 to January 2014 was taken for adipic acid according to Intratec [36]. For polystyrene, the average for 2017 was taken from [37].

Table 3. Economic data for the biochemicals for the base year (2015) adapted from [38-41].

\begin{tabular}{cccccc}
\hline & Units & Ethylene & Succinic Acid & PHA & PLA \\
\hline Plant capacity & $\mathrm{t} / \mathrm{y}$ & 200,000 & 37,500 & 50,000 & 50,000 \\
Investment cost & $€ / \mathrm{t}$ _product & 1291 & 3264 & 5574 & 6509 \\
Operation and maintenance $\%$ of investment) & $\%$ & 7 & 7 & 7 & 7 \\
Feedstock costs & $€ / \mathrm{t}$ & 30.7 & 153 & 153 & 153 \\
Reference Market Price & $€ / \mathrm{t}$ & 960 & 1740 & 1341 & 1341 \\
\hline
\end{tabular}

\subsection{Model Description}

A mathematical optimization model was formulated building upon the methodology from [42,43], in which greenhouse gas optimal allocation of biomass across transport sectors in Germany is described. Scenario analyses were run on the model to assess the potential GHG abatement potentials from 2015 until 2050 and the biomass allocation implications. The model is a bottom up, deterministic linear optimization model that determines the optimal biomass allocation pathways based on maximizing GHG abatement. It is constrained by the available biomass resources, i.e., in this paper agricultural feedstocks cultivated on the available agricultural land, as well as the available conversion capacities for the technologies and the (upper) sectoral demand. These constraining parameter values are imported from an excel spreadsheet and fed to the general algebraic modeling system GAMS model exogenously using MATLAB. The base capacities for the technologies under consideration continuously decommission over time until their end of life and the model decides which technological options to invest into additional capacity based on satisfying the model constraints and the objective function.

\subsubsection{Model Formulation}

The GHG abatement objective function $(\delta \varepsilon)$ is the difference of the life cycle GHG emissions for a reference fossil technology $\left(\varepsilon_{i, t}\right)$ and the life cycle GHG emissions for a biochemical $\left(\varepsilon_{i, t}\right)$ multiplied by the biochemicals production summed up over the technological options and temporal resolution. The production of specific biochemicals $\left(\pi_{i, t}\right)$, which is equal to the amount of feedstocks available $\left(m_{i, t}\right)$ multiplied by the conversion efficiency $\left(\eta_{i}\right)$, should be less than or equal to the yearly available capacities $\left(k_{i, t}\right)$ and the sum of it should be less than or equal to the total substitution potential $\left(\delta_{t}\right)$. The capacity is equal to capacities that have reached their end of life subtracted from the sum of the capacity in the previous year $\left(k_{i, t}\right)$ and the new capacities $k_{i, t+1}^{+}$. The difference of the sum of capacity in the previous year $\left(k_{i, t}\right)$ and in order to ensure that the agricultural land for feedstocks is not over-exploited, the amount of feedstocks available $\left(m_{i, t}\right)$ divided by the agricultural yields $\left(Y_{i, t}\right)$ in all the conversion process should always be less than or equal to the available agricultural land.

$$
\begin{gathered}
\max \varepsilon_{\text {tot }}=\sum_{i, t}\left(\varepsilon_{\text {sub }, t}-\varepsilon_{i, t}\right) * \pi_{i, t} \\
\text { s.t. } \\
\pi_{i, t}=m_{i, t} * \eta_{i} \\
k_{i, t} \geq \pi_{i, t} \\
k_{i, t+1} \leq k_{i, t}+k_{i, t+1}^{+}-k_{i, t-\hat{t}_{i}}^{+}
\end{gathered}
$$




$$
\begin{gathered}
k_{i, t+1}^{+} \leq r+k_{i, t} \\
\delta_{t} \geq \sum_{i} \pi_{i, t} \\
\Lambda_{t} \geq \sum_{i} m_{i, t} *\left(\mathrm{Y}_{i, t}\right)^{-1}
\end{gathered}
$$

where,

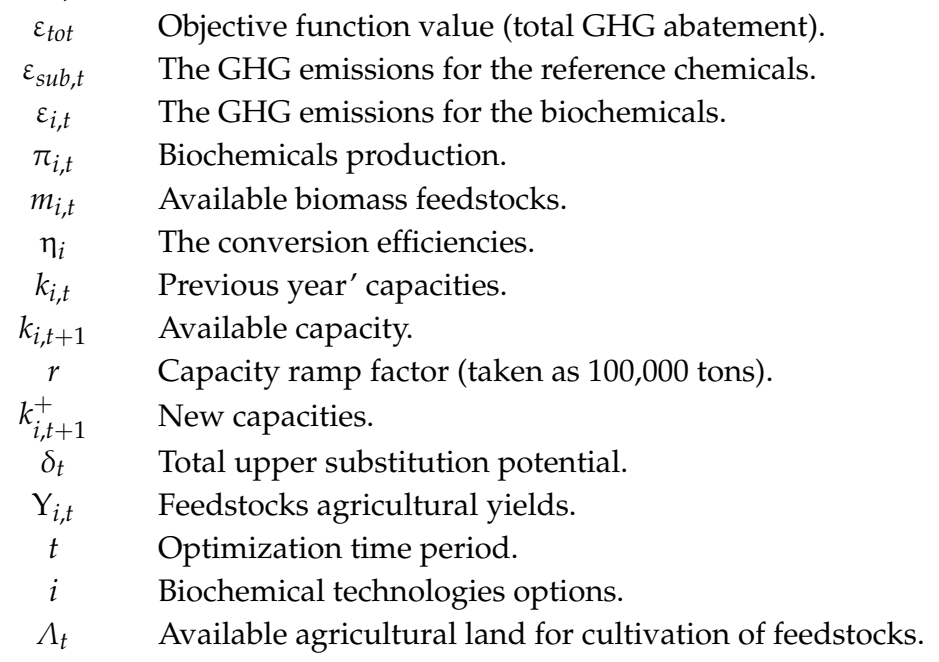

\subsubsection{Feedstock Cost Calculation}

The costs for sugar beets and corn grains were calculated according to the methodology by Millinger detailed in [44]. Using this methodology, feedstock costs were estimated by adding the per hectare profit of wheat (benchmark crop) to the per hectare production costs of the sugar beets and corn grains. The selling price for corn stover, which was used as a credit for corn grain cultivation, was estimated from the costs of corn grains using Equation (10) according to [45]. The value 0.175 is the ratio of the mass of corn grains to the mass of the whole plant on a dry weight basis.

$$
\alpha=0.175 \beta+\mu
$$

where,
$\alpha \quad$ is the price of corn stover in $€ / t_{\mathrm{DM}}$.
$\beta \quad$ is the price of corn grains in $€ / t_{\mathrm{DM}}$.
$\mu \quad$ is the additional cost for harvesting and storage of corn stover taken from [46].

\subsection{Integrated Production and $\mathrm{CO}_{2}$ Sequestration Scenario Analysis}

There is uncertainly related to the usage of the coproducts generated during production of biochemicals and the end of life treatment of bioethylene and biosuccinic acid end products. This leads to different assumptions for life cycle assessments. In this regard, four scenarios for the allocation of biomass to the competing biochemicals were analyzed (summarized in Table 4).

As a reference case, biomass allocation was modeled with the assumption that $\mathrm{CO}_{2}$ uptake during feedstocks cultivation was emitted at the end of life for the end products. Further, integrated production (i.e., use of biochemical coproducts to substitute an equivalent fossil product) was not taken into account.

In the second scenario, further use of biochemicals coproducts is taken into account. Therefore, the GHG abatement as a result of corn stover substituting natural gas in heat generation was subtracted from the overall GHG emissions for succinic acid, PHA, and PLA. Fifty-eight percent of corn stover was assumed to be sustainably harvested according to [47]. In the case of succinic acid, ammonium 
sulphate is also accounted for in the integrated production by subtracting the GHG footprint of fossil ammonium sulphate fertilizer, as reported in [48].

In the third scenario, biomass allocation was optimized by assuming that bioethylene and succinic acid end products are recycled or landfilled after their end of life. The $\mathrm{CO}_{2}$ uptake during cultivation of feedstocks which is eventually sequestered into the final product is then regarded as negative emissions in this scenario. In Section 2.5.1, the procedure for the calculation of the $\mathrm{CO}_{2}$ uptake during cultivation is shown.

Scenario 4 combines the assumptions of scenarios 2 and 3, i.e., fossil equivalent substitution by biochemicals and $\mathrm{CO}_{2}$ sequestration into the biochemicals end products. The different system boundaries for the scenarios are shown in Figure 3.

The upper demand for the biochemicals was assumed to grow linearly to $20 \%$ of the production of fossil-based base chemicals in Germany in 2050. The "Verband der Chemischen Industrie" [49] in their base scenario for the market development of base chemicals in Germany, suggested that chemical production would grow annually by $1.8 \%$ until 2030. In this paper, this growth is assumed until 2050 . The German electricity grid emission factor changes as a result of more renewable power options deployment until 2050 according to world wildlife foundation (WWF) [50] and was used across all the scenarios. The electrical energy requirements for 1 ton of fossil reference chemicals were identified in order to adjust the GHG emissions as the German power mix becomes more renewable. For adipic acid the value is from [51], ethylene from [52], and polystyrene from [53].

Table 4. Scenario description.

\begin{tabular}{cc}
\hline Scenario & Description \\
\hline i & Agricultural yields: 9.3 for corn and $65 \mathrm{tFM} /$ ha sugar beets kept constant \\
$2 \%$ annual wheat price increases \\
$100 \%$ renewable electricity by $2050[50]$
\end{tabular}

The agricultural yields for the feedstocks were kept constant throughout the optimization period. The annual price increases for wheat (benchmark crop) were assumed at $2 \%$ across the scenarios.

The base production capacity for PLA was taken as $500 \mathrm{t} / \mathrm{yr}$. Ethylene, succinic acid, and PHA currently do not have production capacities in Germany. The average production volumes of 2010-2015 for fossil-based ethylene and PS were taken as the maximum upper production for the biochemicals throughout the optimization period. For succinic acid, adipic acid based on a conversion factor of 0.66 [54] to polyurethanes was used. Assumptions for reductions in GHG emissions from fertilizers were taken as $15 \%$ by 2035 and $25 \%$ by 2050 relative to the base year. 


\subsubsection{Feedstock $\mathrm{CO}_{2}$ Uptake Calculation}

The $\mathrm{CO}_{2}$ uptake per ton of fresh matter in the feedstocks during cultivation was estimated based on the carbon content of the feedstocks according to Equation (11):

$$
\omega=\psi * \chi * \tau
$$

where,

$\omega$ is the $\mathrm{CO}_{2}$ uptake by feedstocks, is carbon fraction in the feedstock on a dry weight basis calculated from the

$\psi \quad$ molecular weight of sucrose and starch for sugar beets and corn, respectively,

$\chi \quad$ is the percentage of dry matter in the feedstock, and

$\tau \quad$ is the molecular ratio of $\mathrm{CO}_{2}$ to carbon calculated as shown in Equation (12).

$$
\tau=\frac{[(12+(2 * 16)]}{12}=3.6667
$$

\section{Results}

\subsection{GHG Abatement}

Figure 4 shows the GHG emissions for the biochemicals for the considered scenarios, the corresponding GHG abatement, and the percentage GHG abatement. With German system considerations, it can be deduced that all the biochemicals do not abate GHG in the base year (i.e., 2015) for the first scenario. However, with the increased deployment of renewable electricity into the German power mix, succinic acid and PLA have positive GHG abatement by 2020 and by 2050 they have savings of $73 \%$ and $54 \%$, respectively. PHA in 2050 has an abatement percentage of $52 \%$. Bioethylene does not abate any GHG in this scenario throughout the temporal resolution.

In the second scenario, the performance of succinic acid, PLA, and PHA improves with succinic acid abating the highest GHG per ton with a percentage abatement of $58 \%$. The benefits of coproducts utilization (i.e., integrated production) results in GHG abatements of $11 \%$ and $14 \%$ for PHA and PLA in the base year. Bioethylene still does not abate any GHG for the base year in the second scenario. The GHG abatements increase to $137 \%, 101 \%$, and $84 \%$ for succinic acid, PHA, and PLA, respectively in the year 2050. Corn stover (i.e., the coproduct from feedstocks cultivation), which replaces natural gas for heating purposes, abates fossil GHG emissions. Ammonium nitrate, a coproduct of succinic acid production, similarly replaces fossil ammonium nitrate in fertilizer applications and, therefore, abates fossil GHG emissions. This GHG abatement is subtracted from the GHG emissions of corn cultivation and succinic acid production which in some cases leads to net negative emissions for biochemicals resulting in GHG abatements of more than 100\%.

In the third scenario, bioethylene and succinic acid recorded GHG abatements of $288 \%$ and $127 \%$ in the base year, figures that increased to $304 \%$ and $190 \%$, respectively in 2050 . These substantial abatements are a result of the two drop-in biochemicals acting as carbon sinks because the biogenic $\mathrm{CO}_{2}$ is not emitted at the end of life for biochemicals end products. During cultivation of sugar beets, there is an uptake of $0.31 \mathrm{kgCO}_{2}$ for every kilogram of sugar beet (fresh matter) that is harvested. This translates into negative emissions of $6.7 \mathrm{~km}$ carbon dioxide equivalent $\left(\mathrm{kgCO}_{2} \mathrm{eq}\right)$ per kilogram bioethylene produced. Similarly for succinic acid, there is an uptake of $1.26 \mathrm{kgCO}_{2}$ for every kilogram of corn grains harvested which translates into $3.5 \mathrm{kgCO}_{2}$ eq per $\mathrm{kg}$ succinic acid negative emissions.

In the fourth scenario, GHG abatements for PHA and PLA are the same as in the second scenario while for bioethylene it is the same as in scenario 3. Succinic acid GHG abatement, however, increases to $189 \%$ in the base year and $254 \%$ in 2050 . 

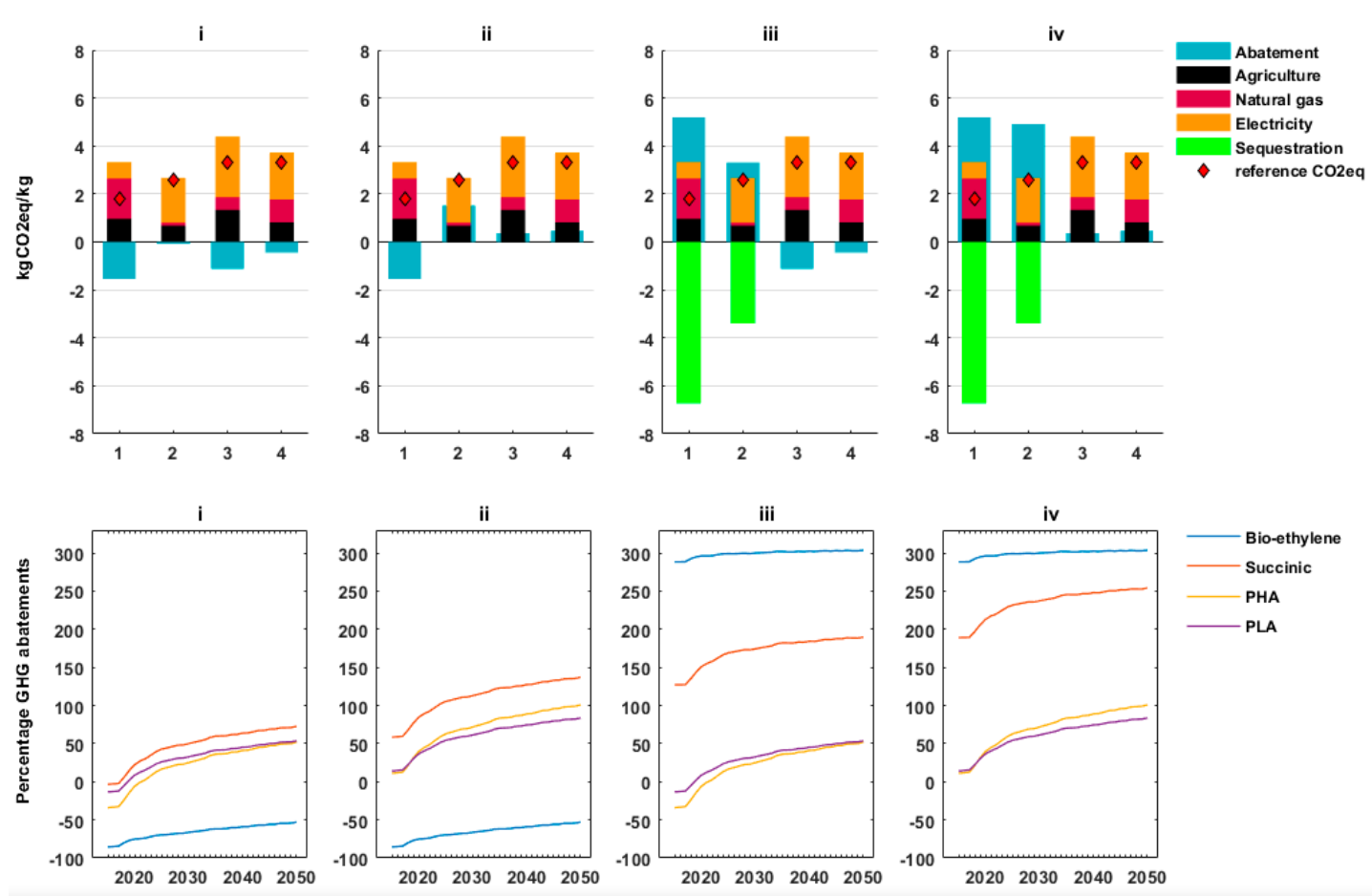

Figure 4. GHG life cycle assessment results. The top part represents shares of the GHG contributions from different production stages in the base year for the scenarios (i, ii, iii, iv). The numbers 1, 2, 3, and 4 on the $x$-axis represent bioethylene, succinic acid, polyhydroxyalkanoates (PHA), and polylactic acid (PLA), respectively. The bottom part shows the percentage abatement increases as a result of grid emission factors reduction due to coal decommissioning and renewable energy deployment in the scenarios (i, ii, iii, iv).

In all the scenarios, for the base year, electricity was the major contributor of GHG emissions for succinic acid, PHA, and PLA followed by emissions from cultivation of feedstocks. For bioethylene, the major GHG emissions contributor is natural gas followed by emissions from cultivation of feedstocks.

The GHG abatement for biochemicals is further represented in $\mathrm{CO}_{2} \mathrm{eq}$ abatement per hectare as shown in Figure 5. Although having a similar GHG abatement per ton product, PLA has a higher GHG abatement per hectare than PHA because it has a higher conversion efficiency.

\subsection{Minimum Selling Prices}

The minimum selling prices for the biochemicals for the "with/without taxes "considerations and the carbon prices necessary for biochemicals breakeven are shown in Figures 6 and 7, respectively. In the first case, all the biochemicals are uncompetitive in comparison with the current reference fossil market prices except for succinic acid. This is because the discounted annual payments towards investment costs and operational costs for succinic acid together with feedstock costs are less than the fossil reference market price. Succinic acid has a relatively higher conversion efficiency which results into lower costs for feedstocks per ton of product produced. The cost of feedstocks contributes the greatest to the overall costs of bioethylene. The costs for ethanol contribute to just below $60 \%$ of bioethylene production costs and corn grains contribute $24 \%, 26 \%$, and $16 \%$ for succinic acid, PHA, and PLA, respectively. The tax rate of $30 \%$ for Germany [31] results into taxation costs ranking as the second contributor to the overall costs for bioethylene and the first for succinic acid and PHA. A carbon price of $421 € / \mathrm{tCO}_{2} \mathrm{eq}$ is necessary for bioethylene to break even and 271 and $245 € / \mathrm{tCO}_{2} \mathrm{eq}$ for PHA and PLA, respectively. Succinic acid is already economically competitive and therefore, requires no carbon price to be profitable. 

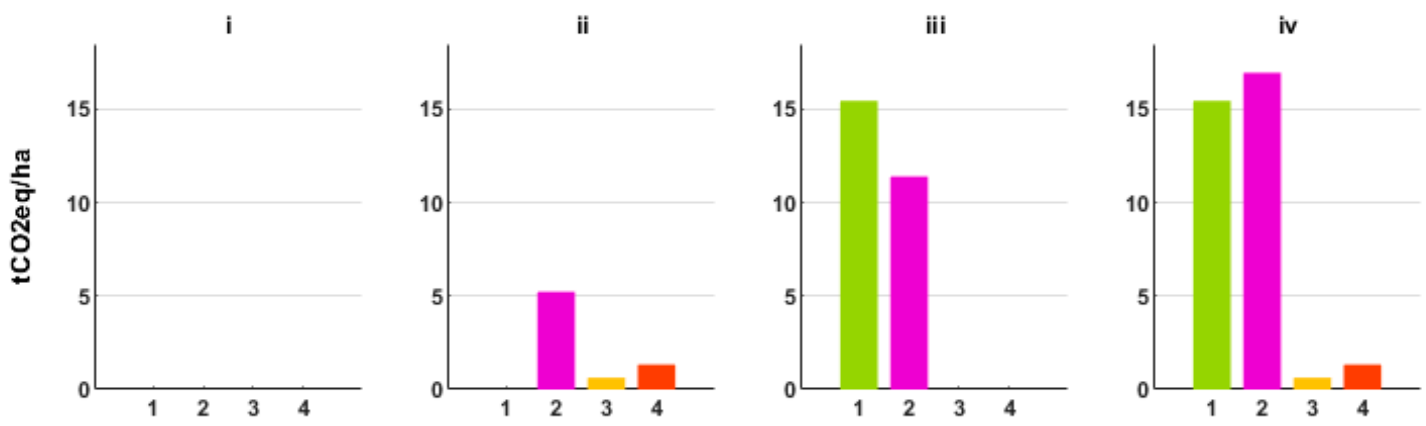

Bio-ethylene

Succinic acid

PHA

PLA

Figure 5. GHG abatement per hectare of agricultural land for the biochemicals in the base year (2015) for the scenarios (i, ii, iii, iv).
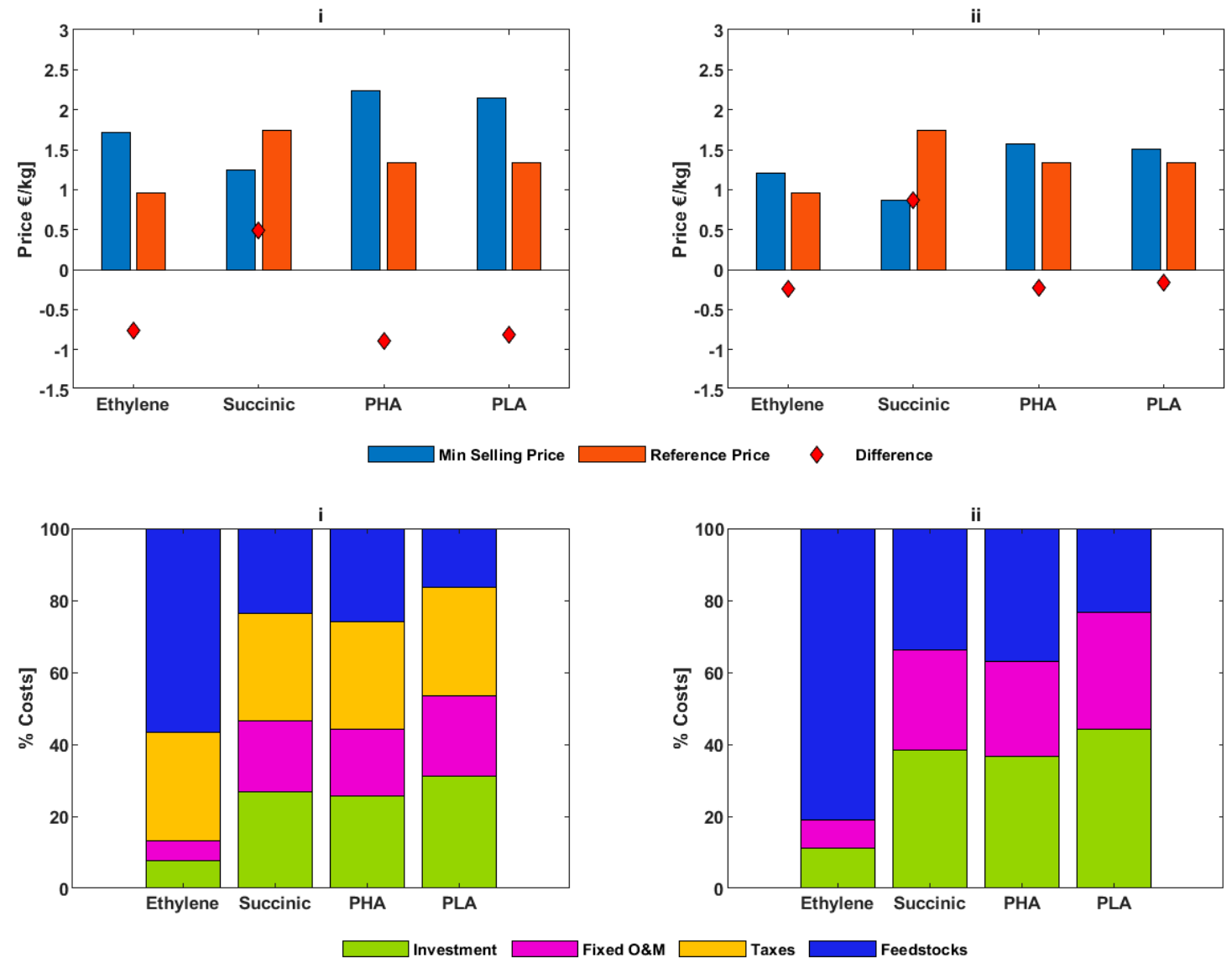

Figure 6. Minimum selling prices in comparison with fossil reference market prices (top part) and cost structures (bottom part) for the base case (i) and 100\% tax relief (ii).

In the case where taxes are completely waived for all the biochemicals, no other biochemical becomes competitive, but their competitiveness improves. The carbon price necessary for bioethylene to break even reduces to $134 € / \mathrm{tCO}_{2}$ eq. For PHA and PLA, this value reduces to 68 and $50 € / \mathrm{tCO}_{2} \mathrm{eq}$, respectively. Succinic acid is even more competitive in the second case and therefore requires no carbon price to be profitable. 


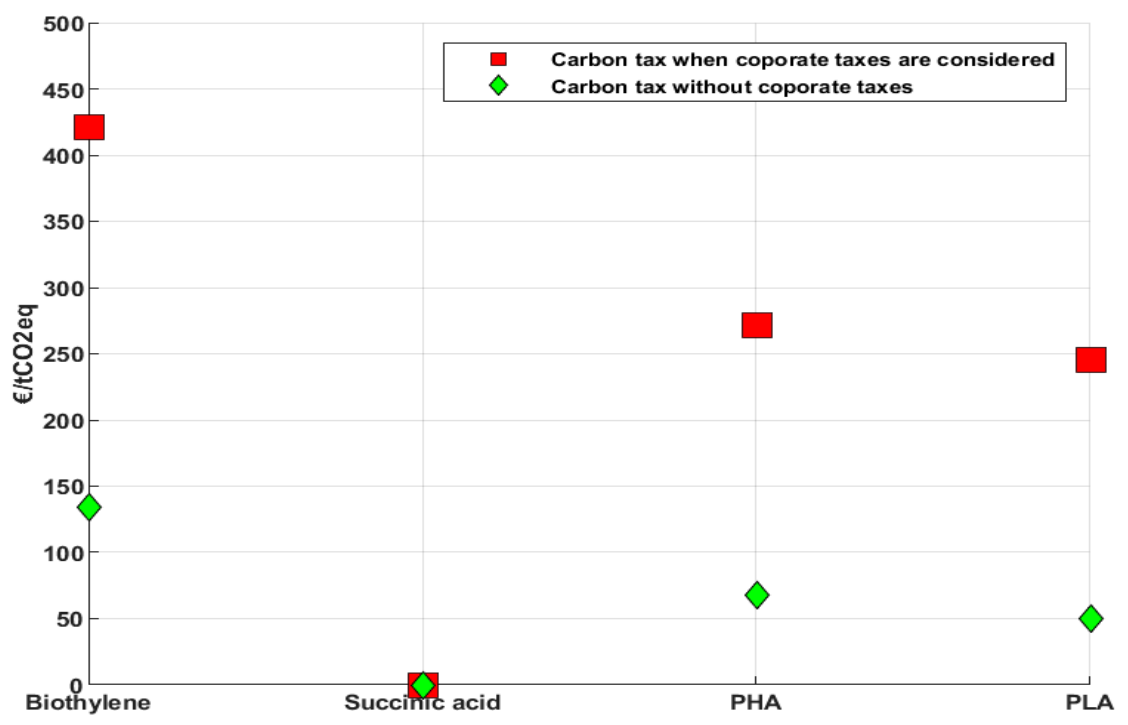

Figure 7. Carbon prices required for biochemicals to break even with/without corporate taxes in Germany. Since succinic acid is already economically competitive in both cases, no carbon price is needed for it to be economically competitive (i.e., zero).

\subsection{Integrated Production and $\mathrm{CO}_{2}$ Sequestration Scenario Analyses on the Optimization Model}

Figure 8 shows the optimal GHG abatement for the biochemicals from available biomass resources for the modeling period in the considered scenarios. In the first scenario, a cumulative GHG abatement of 136 million tons $\mathrm{CO}_{2}$ eq is realized at an abatement cost of $743 € / \mathrm{tCO}_{2}$ eq. Succinic acid is predominantly produced throughout the optimization period with PLA following second in the mid and long term. Cumulative GHG abatement increases to 283 million tons CO2eq and the abatement cost reduced to $380 € / \mathrm{tCO}_{2}$ eq in the second scenario. Succinic acid is produced throughout the optimization period and PHA starts from 2030 onwards. Only bioethylene is produced throughout the third scenario while in the fourth succinic acid and bioethylene are preferably produced. The cumulative GHG abatement and abatement costs for the third scenario are 573 million tons $\mathrm{CO}_{2} \mathrm{eq}$ and $250 € / \mathrm{tCO}$ eq, respectively. In the fourth scenario these are figures are 639 million tons $\mathrm{CO}_{2} \mathrm{eq}$ and $189 € / \mathrm{tCO}$ eq, respectively. In 2050 , the abatements would translate into savings of $16 \%, 30 \%, 68 \%$, and $74 \%$, respectively of energy related GHG emissions for the chemicals sector in Germany for 2014.
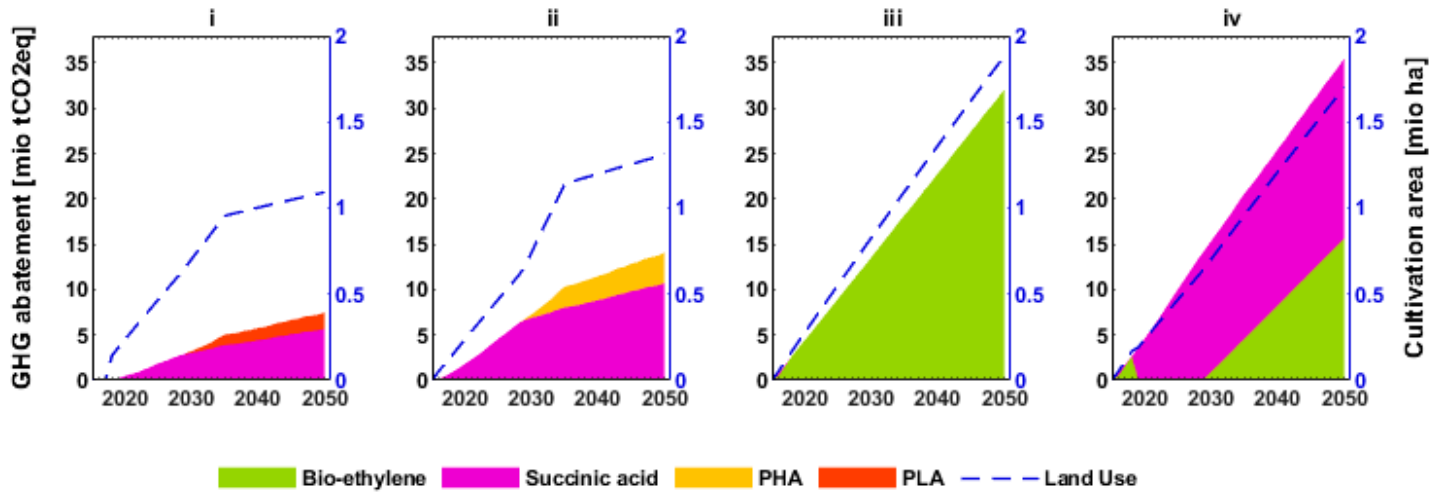

Succinic acid

PHA

PLA - - - Land Use

Figure 8. Biochemicals GHG abatement and the agricultural land demand for the optimization period for the scenarios (i, ii, iii, iv). On the left y-axis is the GHG abatement and on the right is the agricultural land demanded. 


\section{Discussion}

In a number of studies [7,11-13] potential biochemicals have been identified. In addition to the criteria that was used in these studies, the extent of the relevance of biochemicals in terms of fossil reference substitution potential was used in this work to screen biochemicals further for the analysis suiting the German context. Succinic acid with the potential to substitute adipic acid in the manufacture of polyurethanes, bioethylene a direct replacement for fossil-based ethylene, PHA and PLA both that can substitute polystyrene were identified as important biochemicals.

Our analysis show that the integrated production of biochemicals and end of life treatment for biochemicals end products (i.e., cascading) are key issues for GHG abatement and abatement costs: Without measures to ensure $\mathrm{CO}_{2}$ is sequestered into end products (i.e., recycling and no energy recovery for end products at end of life) and integrated production, no biochemical abates GHG for the base year conditions. This is particularly attributed to the high $\mathrm{CO}_{2}$ eq emission factor for the current German power mix. However, as a result of the German government's ambitious target of more renewable electricity by 2050, biochemicals show increased environmental performance. Feasible assumptions for the integration of biochemical coproducts and avoidance of energy recovery from end products of drop-in biochemicals also leads to net GHG savings for biochemicals compared to their fossil counterparts even with the current German power mix. When considered together, integrated production and $\mathrm{CO}_{2}$ sequestration results in improved GHG emissions abatement and reduced abatement costs.

The results of the GHG abatement per hectare for bioethylene and succinic acid in this study confirm the results by Hermann et al. [14], where they argued that biochemicals are preferable to bioenergy in terms of environmental performance. This conclusion based on the environmental performance of biochemicals, however, only holds true if the coproducts generated during the production of biochemicals are used in other applications that substitute fossil resources (i.e., integrated production) and the end products of the biochemicals are not used for energy recovery at their end of life.

Except for succinic acid, the selected biochemicals are not economically competitive even in an ambitious case of full tax waivers. Since economic feasibility is the ultimate decider for the establishment of any investment, biochemicals deployment based on this metric is not feasible. Succinic acid, having no technical and economic barriers would only need measures such as production quotas for chemicals from renewable resources by petrochemical companies in order to play an active role in GHG abatement. Feedstock costs for bio-ethylene were found to be the major contributor to the overall costs and for other biochemicals the costs of feedstocks were comparable with investment costs. Biochemicals production costs could be significantly reduced by a corresponding reduction in feedstock costs. Efforts into reducing agricultural feedstocks costs such as improved agricultural yields and conversion efficiencies and research into advanced feedstocks for ethanol production could reduce the total costs of biochemicals.

The results for agricultural land requirements for feedstocks cultivation were over 1 million hectares by 2050 across all scenarios. Therefore, the debate regarding the competition of first generation feedstocks with food [55-57] which lessens public support [58,59] as cited in [60] could emerge as a barrier to biochemicals deployment. In this regard, second generation feedstocks (lignocellulosic biomass) such as short rotation woody crops, agricultural/forest residues, etc. could become relevant.

In the 2018 "intergovernmental panel on climate change (IPCC)special report on the impacts of global warming of $1.5^{\circ} \mathrm{C}$ above pre-industrial levels and related global greenhouse gas emission pathways" [61], bioenergy with carbon capture and storage (BECCS) is relevant as a mitigation option for three out of the four pathways they considered. In the global energy and transportation model (GET 5.0), it was determined that negative emissions are necessary in order to meet stringent $\mathrm{CO}_{2}$ stabilization targets (i.e., 350 parts per million (ppm)), which also makes BECCS a relevant option [62]. However, carbon capture and storage has among other disadvantages such as the risk of leakage and high costs which do not justify investments if they are more than the carbon price [63]. The benefit of 
negative emissions can, however, be realized by drop-in biochemicals without the aspects of risk of leakage and costs associated with capture and storage from bioenergy. This coupled with the fact that succinic acid is currently economically competitive when compared to the fossil reference market price is an advantage. The bioethylene margin could become positive with full tax exemption and a carbon price on the fossil reference of $134 € / \mathrm{tCO}_{2} \mathrm{eq}$.

Retention times are crucial for negative emissions, hence PLA and PHA were disregarded from carbon sequestration consideration because they biodegrade with time. As a result of landfilling restrictions in Germany stemming from the "Circular Economy Act (KrWG)" [64], the best carbon sequestration strategy for biochemicals would be recycling (no energy recovery) of end products after end of life. In addition to the benefits of negative emissions, recycling would facilitate double abatement because recycled plastics (i.e., the majority of end products from ethylene and adipic acid) have a lower GHG footprint than virgin plastics $[65,66]$.

\section{Conclusions}

In this paper, biochemicals with the potential to substitute fossil-based chemicals were identified; their environmental and economic performances and the potential GHG abatement from available biomass in Germany between 2015 and 2050 were assessed, and the corresponding abatement costs determined. The environmental performances were done considering four different scenarios derived from assumptions regarding system boundaries.

The main conclusion from the results is that integrated production of biochemicals and measures that ensure $\mathrm{CO}_{2}$ sequestration into biochemical end products (i.e., no energy recovery from end products after end of life and end products recycling and/or landfilling) significantly increases the GHG abatement of biochemicals, thereby reducing the abatement costs. Within the considered system boundaries, the potential cumulative GHG abatement until 2050 and the abatement costs at which this is achieved varied significantly. Cumulative GHG abatements increased by $110 \%, 320 \%$, and $370 \%$, respectively relative to the base scenario while abatement costs reduced by $49 \%, 68 \%$, and $75 \%$, respectively relative to the base scenario. However, reduced abatement costs do not imply a corresponding reduction in production costs. Production costs determine the economic viability of biochemicals when compared to market prices for the fossil derived chemical and are therefore crucial in assessing the chemical sector transformation.

To start the transformation from fossil derived chemicals to biochemicals, with an exception of succinic acid, a minimum $\mathrm{CO}_{2}$ tax of $421 € / \mathrm{tCO}_{2}$ eq is needed as an initial measure in order to make the assessed biochemicals economically competitive. Other measures aimed at reducing feedstock costs, such as improved conversion efficiencies and further research into advanced feedstocks which are readily available and tax incentives could further support the transformation process.

Author Contributions: Conceptualization, F.M. and M.M.; methodology, F.M.; modeling, F.M.; investigation, F.M.; resources, D.T.; data curation, F.M.; writing-original draft preparation, F.M.; writing-review and editing, F.M., M.M., and D.M.; visualization, F.M.; supervision, M.M. and D.T.; funding acquisition, M.M. and D.T. All authors have read and agreed to the published version of the manuscript.

Funding: This research was funded by the Bundesministerium für Bildung und Forschung, grant number 031B0232E.

Acknowledgments: This work was funded by the Bundesministerium für Bildung und Forschung (031B0232E) and supported by Helmholtz Impulse and Networking Fund through Helmholtz Interdisciplinary Graduate School for Environmental Research (HIGRADE).

Conflicts of Interest: The authors declare no conflict of interest. The funders had no role in the design of the study; in the collection, analyses, or interpretation of data; in the writing of the manuscript, or in the decision to publish the results. 


\section{References}

1. Directive 2009/28/EC of the European Parliament and of the Council of 23 April 2009 on the Promotion of the Use of Energy from Renewable Sources and Amending and Subsequently Repealing Directives 2001/77/EC and 2003/30/EC; European Commission: Brussels, Belgium, 2009.

2. Directive 2018/2001 of the European parliament and of the council of 11 December 2018 on the Promotion of the Use of Energy from Renewable Sources (Recast). 2018. Available online: https://eur-lex.europa.eu/legalcontent/EN/TXT/PDF/?uri=CELEX:32018L2001\&from=EN (accessed on 23 May 2019).

3. Josling, T.; Blandford, D.; Earley, J. Biofuel and Biomass Subsidies in the U.S., EU and Brazil: Towards a Transparent System of Notification. In IPC Position Paper; International Food and Agricultural Trade Policy Council: Washington, DC, USA, 2010.

4. Charles, C.; Gerasimchuk, I.; Bridle, R.; Moerenhout, T.; Asmelash, E.; Laan, T. Biofuels-At What Cost? A Review of Costs and Benefits of EU Biofuel Policies; The International Institute for Sustainable Development: Geneva, Switzerland, 2013.

5. Heinimö, J.; Junginger, M. Production and trading of biomass for energy-An overview of the global status. In Proceedings of the 15th European Biomass Conference \& Exhibition, Berlin, Germany, 7-11 May 2007.

6. FNR. Bioenergy in Germany Facts and Figures 2016; Fachagentur Nachwachsende Rohstoffe e. V.: FNR: Gülzow-Prüzen, German, 2017.

7. Ed de Jong, E.; Higson, A.; Walsh, P.; Wellisch, M. Bio-based ChemicalsValue Added Products from Biorefineries. In IEA Bioenergy Task42 Biorefinery; IEA Bioenergy: Wageningen, The Nertherlands, 2014.

8. Rasch, M.; Regett, A.; Pichlmaier, S.; Conrad, J.; Greif, S.; Guminksi, A. Eine anwendungsorientierte Emissionsbilanz. BWK Das Energ. Fachmag. 2017, 69, 80-84.

9. Bazzanella, A.M.; Ausfelder, F. Low Carbon Energy and Feedstock for the European Chemical Industry; DECHEMA Gesellschaft für Chemische Technik und Biotechnologie e.V.: Frankfurt am Main, Germany, 2017.

10. Manfred, F.; Joyashree, R.; Adolf, A.; Julian, A.; Jean-Paul, C.; Yong, G.; Haroon, K.; Alessandro, L.; Daniel, P.; Lynn, P.; et al. Industry In: Climate Change 2014: Mitigation of Climate Change: ContriContribution of Working Group III to the Fifth Assessment Report of the Intergovernmental Panel on Climate Change. Technical Report; Edenhofer, O., Pichs-Madruga, R., Sokona, Y., Farahani, E., Kadner, S., Seyboth, K., Adler, A., Baum, I., Brunner, S., Eickemeier, P., et al., Eds.; Cambridge University Press: New York, NY, USA, 2014.

11. E4tech; RE-CORD; WUR. From the Sugar Platform to Biofuels and Biochemical. Final report for the European Commission, Contract No. ENER/C2/423-2012/SI2.673791. 2015. Available online: https: //ec.europa.eu/energy/sites/ener/files/documents/EC\%20Sugar\%20Platform\%20final\%20report.pdf (accessed on 15 January 2019).

12. Bozell, J.J.; Petersen, G.R. Technology development for the production of biobased products from biorefinery carbohydrates-The US Department of Energy's “Top 10" revisited. Green Chem. 2010, 12, 539-554. [CrossRef]

13. Werpy, T.; Petersen, G.; Aden, A.; Bozell, J.; Holladay, J.; White, J.F.; Manheim, A.; Eliot, D.; Lasure, J.; Jones, S. Top Value Added Chemicals from Biomass: Volume 1-Results of Screening for Potential Candidates from Sugars and Synthesis Gas; National Renewable Energy Lab.: Golden, CO, USA, 2004.

14. Hermann, B.G.; Blok, K.; Patel, M.K. Producing Bio-Based Bulk Chemicals Using Industrial Biotechnology Saves Energy and Combats Climate Change. Environ. Sci. Technol. 2007, 41, 7915-7921. [CrossRef] [PubMed]

15. Adom, F.; Dunn, J.B.; Han, J.; Sather, N. Life-cycle fossil energy consumption and greenhouse gas emissions of bioderived chemicals and their conventional counterparts. Environ. Sci. Technol. 2014, 48, 14624-14631. [CrossRef]

16. Hermann, B.G.; Patel, M. Today's and tomorrow's bio-based bulk chemicals from white biotechnology. Appl. Biochem. Biotechnol. 2007, 136, 361-388. [CrossRef]

17. Bentsen, N.S.; Jack, M.W.; Felby, C.; Thorsen, B.J. Allocation of biomass resources for minimising energy system greenhouse gas emissions. Energy 2014, 69, 506-515. [CrossRef]

18. Codina Gironès, V.; Moret, S.; Peduzzi, E.; Nasato, M.; Maréchal, F. Optimal use of biomass in large-scale energy systems: Insights for energy policy. Energy 2017, 137, 789-797. [CrossRef]

19. König, A. Cost efficient utilisation of biomass in the German energy system in the context of energy and environmental policies. Energy Policy 2011, 39, 628-636. [CrossRef]

20. Vadenbo, C.; Tonini, D.; Astrup, T.F. Environmental Multiobjective Optimization of the Use of Biomass Resources for Energy. Environ. Sci. Technol. 2017, 51, 3575-3583. [CrossRef] 
21. Verband der Chemischen Industrie e. V. (VC.I). Chemiewirtschaft in Zahlen 2018; Verband der Chemischen Industrie e. V. (VC.I): Frankfurt am Main, Germany, 2018.

22. Petrochemicals Europe. The Petrochemicals Europe Flowchart. Available online: https://www.petrochemistry. eu/about-petrochemistry/flowchart/ (accessed on 3 June 2019).

23. Eseyin, A.E.; Steele, P.H. An overview of the applications of furfural and its derivatives. J. Adv. Chem. 2015, 3, 42. [CrossRef]

24. Jungbluth, N.; Chudacoff, M.; Dauriat, A.; Dinkel, F.; Doka, G.; Faist Emmenegger, M.; Gnansounou, E.; Kljung, N.; Schleiss, K.; Spielmann, M.; et al. Life Cycle Inventories of Bioenergy; Ecoinvent Report No. 17; Swiss Centre for Life Cycle Invetories: Dübendorf, Switzerland, 2007.

25. Siebert, S.; Döll, P. Ecoinvent 3.6 dataset documentation: Quantifying blue and green virtual water contents in global cro production as well as potential production losses without irrigation. J. Hydrol. 2010, 384, 198-217. [CrossRef]

26. Meisel, K.; Braune, M.; Gröngröft, A.; Majer, S.; Müller-Langer, F.; Naumann, K. Technical Principles and Methodology for Calculating GHG Balances of Bioethanol: Guidance Document: Version 1.0.; DBFZ German Biomass Research Center gGmbH: Leipzig, Germany, 2016.

27. Liptow, C.; Tillman, A.-M. Comparative Life Cycle Assessment of Polyethylene Based on Sugarcane and Crude Oil; Chalmers University of Technology: Göteborg, Sweden, 2009.

28. Groot, W.J.; Borén, T. Life cycle assessment of the manufacture of lactide and PLA biopolymers from sugarcane in Thailand. Int. J. Life Cycle Assess 2010, 15, 970-984. [CrossRef]

29. Moussa, H.I.; Elkamel, A.; Young, S.B. Assessing energy performance of bio-based succinic acid production using LCA. J. Clean. Prod. 2016, 139, 761-769. [CrossRef]

30. Zhong, Z.W.; Song, B.; Huang, C.X. Environmental Impacts of Three Polyhydroxyalkanoate (PHA) Manufacturing Processes. Mat. Manuf. Process. 2009, 24, 519-523. [CrossRef]

31. Deloitte. Corporate Tax Rates 2018. Deloitte. 2019. Available online: https://www2.deloitte.com/content/ dam/Deloitte/global/Documents/Tax/dttl-tax-corporate-tax-rates.pdf (accessed on 5 June 2019).

32. Cherowbrier, J. Euro to U.S. dollar annual average exchange rate 1999-2018: Statista. 2019. Available online: https://www.statista.com/statistics/412794/euro-to-u-s-dollar-annual-average-exchange-rate/ (accessed on 29 October 2019).

33. Eurostat. Selling Prices of Sugar Beet (Unit Value): Eurostat, the Statistical Office of the European Union. Available online: https:/data.europa.eu/euodp/en/data/dataset/mw9PGtsnJTkjaFash58uw/resource/ 868d6bb4-062e-43c0-b8e5-9e76c2de3a4f (accessed on 28 October 2019).

34. Proplanta. Markt \& Preis: MATIF Mais. Available online: https://www.proplanta.de/Markt-und-Preis/ MATIF-Mais/ (accessed on 5 June 2019).

35. Hohmann, M. Preisentwicklung ausgewählter Basischemikalien in Deutschland bis 2018. Available online: https://de.statista.com/statistik/daten/studie/954325/umfrage/preisentwicklung-ausgewaehlterbasischemikalien-in-deutschland/ (accessed on 29 October 2019).

36. Intratec. Adipic Acid Prices: Current Prices, Historical Series and Forecasts in Several Countries. Available online: https://www.intratec.us/chemical-markets/adipic-acid-price (accessed on 17 May 2019).

37. myCEPPI. Market Prices for Commodities in Central and Eastern Europe: Plastiker. 2019. Available online: https://plasticker.de/preise/preise_myceppi_en.php?kw=2\&jahr=2019\#hist (accessed on 17 May 2019).

38. Roland-Holst, D.; Triolo, R.; Heft-Neal, S.; Bayrami, B. Economic Assessment of Market Conditions for PHA/PHB Bioplastics Produced from Waste Methane; University of California: Berkeley, CA, USA, 2013.

39. Tides Center/Environmental Health Strategy Center, Maine Initiatives with Jim Lunt \& Associates, LLC. In The Business Case for Commercial Production of Bioplastics in Maine; Maine Technology Institute: Brunswick, GA, USA, 2010.

40. Vaswani, S. PEP Review 2010-14-Bio-Based Succinic Acid; SRI Consult.: CA, USA, 2010.

41. IEA-ETSAP, IRENA. Production of Bio-ethylene: Technology Brief; International Renewable Energy Agency: Abu Dhabi, UAE, 2013.

42. Millinger, M. BioENergyOPTimisation Model: Zenodo. 2019. Available online: https://zenodo.org/record/ 2812986\#.XmoNOqhKg2w (accessed on 5 June 2019).

43. Millinger, M.; Meisel, K.; Thrän, D. Greenhouse gas abatement optimal deployment of biofuels from crops in Germany. Transp. Res. Part D Transp. Environ. 2019, 69, 265-275. [CrossRef] 
44. Millinger, M.; Thrän, D. Biomass price developments inhibit biofuel investments and research in Germany: The crucial future role of high yields. J. Clean. Prod. 2018, 172, 1654-1663. [CrossRef]

45. Hendrix, K.S. Determining a Value for Silage Crops. Department of Animal Sciences Purdue University. Available online: https://www.ansc.purdue.edu/beef/Hendrix/silagecrop.htm (accessed on 12 October 2019).

46. Paulson, N.; Khanna, M. To Harvest Stover or Not: Is it Worth It? Available online: https://policymatters. illinois.edu/to-harvest-stover-or-not-is-it-worth-it/ (accessed on 6 August 2019).

47. Wyman, C.E.; Hinman, N.D. Ethanol-Fundamentals of production from renewable feedstocks and use as a transportation fuel. Appl. Biochem. Biotechnol. 1990, 24-25, 735-753. [CrossRef]

48. Brentrup, F.; Hoxha, A.; Christensen, B. Carbon footprint analysis of mineral fertilizer production in Europe and other world regions. In Proceedings of the 10th International Conference on Life Cycle Assessment of Food, Dublin, Ireland, 19-21 October 2016.

49. Verband der Chemischen Industrie e. V. (VCI). Basic Chemicals Production 2030; Verband der Chemischen Industrie e. V. (VCI): Frankfurt am Main, Germany, 2012.

50. WWF. Zukunft Stromsystem: Kohleausstieg 2035-Vom Ziel Her Denken; World Wildlife Foundation: Berlin, Germany, 2017.

51. Towler, G.P.; Sinnott, R.K. Chemical Engineering Design: Principles, Practice, and Economics of Plant and Process Design, 2nd ed.; Towler, G., Sinnott, R., Eds.; Butterworth-Heinemann: Boston, MA, USA, 2013.

52. Worrell, E.; Price, L.; Neelis, M.; Galitsky, C.; Nan, Z. World Best Practice Energy Intensity Values for Selected Industrial Sectors; Environmental Energy Technologies Division Lawrence Berkeley National Laboratory: Berkeley, CA, USA, 2007.

53. Ricart, C.; Schweiger, H.; Vannoni, C. Production of Expanded Polystyrene. In Energy Audit Summary Report Audit No. 19-ESP02 Plastic Industry. Available online: https://www.einstein-energy.net/images/ uploads/AuditSummaries/EINSTEIN_audit_summaryreport_19.pdf (accessed on 10 January 2020).

54. Orbichem. Chemical Conversion Factors: Orbichem. Available online: https://www.orbichem.com/ chemicalconversionfactors.aspx (accessed on 8 August 2019).

55. Johansson, D.J.A.; Azar, C. A scenario based analysis of land competition between food and bioenergy production in the US. Clim. Chang. 2007, 82, 267-291. [CrossRef]

56. Valentine, J.; Clifton-Brown, J.; Hastings, A.; Robson, P.; Allison, G.; Smith, P. Food vs. fuel: The use of land for lignocellulosic 'next generation' energy crops that minimize competition with primary food production. Glob. Chang. Biol. Bioenergy 2012, 4, 1-19. [CrossRef]

57. Searchinger, T.; Heimlich, R. Avoiding Bioenergy Competition for Food Crops and Land. In Working Paper, Installment 9 of Creating a Sustainable Food Future; World Resources Institute: Washington, DC, USA, 2015; Available online: http://www.worldresourcesreport.org (accessed on 10 November 2019).

58. Alasti, E. Social Acceptance of Bioenergy in Europe; IIIEE, Lund University: Lund, Sweden, 2011.

59. Thompson, P. The Agricultural Ethics of Biofuels: The Food vs. Fuel Debate. Agriculture 2012, 2, 339-358.

60. Belden Russanello and Stewart. Public Opinion on Federal Farm and Biofuels Policy: Highlights from the 2010 Survey on Agriculture and the Environment. Available online: http:/www.farmsfoodandfuel.org/ system/files/BRS\%202010\%20Poll\%20Highlights_2.pdf (accessed on 10 January 2020).

61. IPCC. Summary for Policymakers. In Global Warming of $1.5^{\circ} \mathrm{C}$. An Ipcc Special Report on the Impacts of Global Warming of $1.5^{\circ} \mathrm{C}$ Above Pre-Industrial Levels and Related Global Greenhouse Gas Emission Pathways, in the Context of Strengthening the Global Response to the Threat of Climate Change, Sustainable Development, and Efforts to Eradicate Poverty; Masson-Delmotte, V., Zhai, P., Pörtner, H.O., Roberts, D., Skea, J., Shukla, P.R., Pirani, A., Moufouma-Okia, W., Péan, C., Pidcock, R., et al., Eds.; Intergovernmental Panel on Climate Change: Geneva, Switzerland, 2018.

62. Azar, C.; Lindgren, K.; Larson, E.; Möllersten, K. Carbon Capture and Storage from Fossil Fuels and Biomass - Costs and Potential Role in Stabilizing the Atmosphere. Clim. Chang. 2006, 74, 47-79. [CrossRef]

63. Ajayi, T.; Gomes, J.S.; Bera, A. A review of $\mathrm{CO}_{2}$ storage in geological formations emphasizing modeling, monitoring and capacity estimation approaches. Pet. Sci. 2019, 16, 1028-1063. [CrossRef]

64. Gesetz zur Förderung der Kreislaufwirtschaft und Sicherung der umweltverträglichen Bewirtschaftung von Abfällen (Kreislaufwirtschaftsgesetz-KrWG); Salzwasser Verlag: Paderborn, Germany, 2013. 
65. Franklin Associates. Life cCycle Impacts for Postconsumer Recycled Resins: PET, HDPE, and PP; The Association of Plastic Recyclers: Washington, DC, USA, 2018.

66. Storm, B.K. Production of recyclates-compared with virgin Plastics-A LCA Study. In Proceedings of the MATEC Web of Conferences, Lasi, Romania, 24-27 May 2017; Volume 112, p. 4024.

(C) 2020 by the authors. Licensee MDPI, Basel, Switzerland. This article is an open access article distributed under the terms and conditions of the Creative Commons Attribution (CC BY) license (http://creativecommons.org/licenses/by/4.0/). 